\title{
POSSIBILITY OF CARBON DIOXIDE SEQUESTRATION BY CATCH CROPS
}

\section{MOŻLIWOŚĆ SEKWESTRACJI DITLENKU WĘGLA PRZEZ MIĘDZYPLONY}

\begin{abstract}
The global fluxes of carbon in the ecosystem of Earth, with particular attention drawn to the cycle of $\mathrm{CO}_{2}$ were characterised. The sequestration of carbon dioxide in the biomass of plants, especially the ones which can be cultivated as catch crops is described. It was shown that the cultivation of catch crops may play an important role in the mitigation of $\mathrm{CO}_{2}$ emissions.
\end{abstract}

Keywords: mitigation of carbon dioxide emissions, climate change, absorption of carbon dioxide by catch crops

\section{Introduction}

According to the reports by Intergovernmental Panel for Climate Change [1-3], the emission of greenhouse gases causes a climate change with negative consequences for earth ecosystems.

One of the reasons is the growing emission of $\mathrm{CO}_{2}$ produced during the combustion of fossil fuels and cement production, which has been on increase since the Industrial Revolution that started in 1769 with the modernization of a steam engine by James Watt, originally built in 1712 by Thomas Newcomen. The second ground-breaking invention was the replacement of charcoal used in metallurgy by coke in 1735 [4]. Since than the intense consumption of fossil fuels has been observed, resulting in a growing emission of $\mathrm{CO}_{2}$ from their combustion. Until 1760, the global emission of $\mathrm{CO}_{2}$ amounted to $11 \mathrm{Tg} \mathrm{CO}_{2} / \mathrm{yr}$ $\left(0.011 \mathrm{Gt} \mathrm{CO}_{2} / \mathrm{yr}\right)$. Since then, the emission of $\mathrm{CO}_{2}$ from anthropogenic sources started to increase. An especially dramatic growth in the $\mathrm{CO}_{2}$ emission occurred after 1956, reaching the value of $36.8 \mathrm{Pg} \mathrm{CO}_{2} / \mathrm{yr}$ in 2017 (see Table 1).

Simultaneously, changes in land use, mainly caused by deforestation, also contributed to the growth of $\mathrm{CO}_{2}$ emission (Table 1).

\footnotetext{
${ }^{1}$ Faculty of Environmental Engineering, Lublin University of Technology, ul. Nadbystrzycka 40B, 20-618 Lublin, Poland, phone +48815384402

${ }^{2}$ University of Life Science in Lublin, ul. Akademicka 13, 20-033 Lublin, Poland

${ }^{3}$ Zhejiang A and F University, Lin'an, Hangzhou, Zhejiang 311300, China

*Corresponding author: 1.pawlowski@pollub.pl
} 
Global $\mathrm{CO}_{2}$ emission from anthropogenic sources [5]

\begin{tabular}{|c|c|c|}
\hline Year & $\begin{array}{c}\text { Industrial emissions } \\
{\left[\mathbf{P g} \mathbf{C O}_{2} / \mathbf{y r}\right]}\end{array}$ & $\begin{array}{c}\text { Land use change emissions } \\
{\left[\mathbf{P g} \mathbf{C O}_{2} / \mathbf{y r}\right]}\end{array}$ \\
\hline before 1760 & 0.011 & - \\
\hline 1880 & 0.28 & - \\
\hline 1956 & 7.98 & - \\
\hline $1960-1969$ & 11.37 & 5.50 \\
\hline $1970-1979$ & 17.23 & 4.77 \\
\hline $1980-1989$ & 20.17 & 5.13 \\
\hline $1990-1999$ & 23.47 & 5.87 \\
\hline $2000-2009$ & 28.60 & 3.67 \\
\hline $2005-2014$ & 33.00 & 3.3 \\
\hline 2014 & 35.93 & 4.03 \\
\hline 2015 & 36.30 & 4.77 \\
\hline 2016 & 36.20 & 4.77 \\
\hline 2017 & 36.8 & - \\
\hline
\end{tabular}

An increase in the $\mathrm{CO}_{2}$ emission to the atmosphere led to its increased concentration in atmosphere from $280 \mathrm{ppm}$ prior to the Industrial Revolution to $313.7 \mathrm{ppm}$ in the critical year 1956; since then, its concentration grew rapidly reaching $404.0 \mathrm{ppm}$ in 2017 (see Table 2). According to IPCC reports [1-3], such high increase in the atmospheric $\mathrm{CO}_{2}$ concentration leads to the warming of the climate, which causes serious disruption in the earth ecosystems.

Concentration of $\mathrm{CO}_{2}$ in atmosphere $[6,7]$

Table 2

\begin{tabular}{|c|c|}
\hline Year & CO $_{2}$ [ppm] \\
\hline before 1780 & $<280.0$ \\
\hline 1860 & 286.0 \\
\hline 1890 & 292.0 \\
\hline 1930 & 307.1 \\
\hline 1950 & 312.0 \\
\hline 1956 & 313.7 \\
\hline 1966 & 320.6 \\
\hline 1976 & 331.2 \\
\hline 1986 & 345.7 \\
\hline 1996 & 362.6 \\
\hline 2006 & 381.9 \\
\hline 2016 & 404.2 \\
\hline 2017 & 406.6 \\
\hline 2018 & 408.5 \\
\hline
\end{tabular}

In order to prevent the adverse climate changes, actions are taken to mitigate the $\mathrm{CO}_{2}$ emission to prevent a rise in temperature by more than $1.5^{\circ} \mathrm{C}$ [8]. One of the directions is reduction of the combustion of fossil fuels and reduction of $\mathrm{CO}_{2}$ emission by technical solutions $[9,10]$ on the one hand, and sequestering $\mathrm{CO}_{2}$ on the other [11].

Two major fluxes should be distinguished in the global $\mathrm{CO}_{2}$ cycle within the Earth ecosystem: 
- absorption of $\mathrm{CO}_{2}$ by terrestrial ecosystems in the photosynthesis process, which equals $450 \mathrm{Pg} \mathrm{CO}_{2} / \mathrm{yr}$. Simultaneously, respiration of plant and soil organisms and fires emit $435 \mathrm{Pg} \mathrm{CO}_{2} / \mathrm{yr}$ into the atmosphere [2];

- $\quad$ absorption of $\mathrm{CO}_{2}$ by surface waters, mostly oceans, which amounts to $293 \mathrm{Pg} \mathrm{CO}_{2} / \mathrm{yr}$. Simultaneously, $284 \mathrm{Pg} \mathrm{CO}_{2} / \mathrm{yr}$ is emitted into the atmosphere as a result of degassing.

These systems are responsible for the removal of a certain amount of $\mathrm{CO}_{2}$ from the atmosphere.

The greatest possibilities of removing $\mathrm{CO}_{2}$ from the atmosphere are connected with an appropriate control of the $\mathrm{CO}_{2}$ exchange between the atmosphere and terrestrial ecosystems. For instance, it would be sufficient to increase the absorption of $\mathrm{CO}_{2}$ in the photosynthesis processes by $8.2 \%$ to completely mitigate the emission from the combustion of fossil fuels and cement production processes.

Taking into account the current trends of development, reduction the $\mathrm{CO}_{2}$ emission is not easy. It is inextricably connected with the supply of energy, which drives the development of our civilization [12]. Therefore, it is necessary to seek more efficient $\mathrm{CO}_{2}$ sinks. The natural ones include the absorption in ocean waters and terrestrial absorption in biomass and geological strata. It was observed that the net amount of the $\mathrm{CO}_{2}$ absorbed in oceans increased from $3.7 \mathrm{Pg} \mathrm{CO}_{2} / \mathrm{yr}$ in $1960-1969$ to $9.5 \mathrm{Pg} \mathrm{CO}_{2} / \mathrm{yr}$ in 2016 [5]. However, it is predicted that the share of this sink will decrease with time, as a result of ocean water acidification. The studies carried out by Le Quere et al. [5] shows that starting from the 1960s, the share of another important sink, i.e. net absorption of $\mathrm{CO}_{2}$ by plants, is on the increase. It grows from 5.1 $\mathrm{Pg} \mathrm{CO}_{2} / \mathrm{yr}$ in 1960-69 to $11.0 \mathrm{Pg} \mathrm{CO}_{2} / \mathrm{yr}$ in 2007-2016, reaching $8.9 \mathrm{Pg} \mathrm{CO}_{2} / \mathrm{yr}$ in 1970-1979, 9.2 $\mathrm{Pg} \mathrm{CO}_{2} / \mathrm{yr}$ in 1990-1999 and $10.6 \mathrm{Pg} \mathrm{CO}_{2} / \mathrm{yr}$ in 2000-2009. In 2016, its value reached at $9.9 \mathrm{Pg} \mathrm{CO}_{2} / \mathrm{yr}$, which was lower than the average from the previous decade.

There are further possibilities of enhancing the $\mathrm{CO}_{2}$ sequestration, both by terrestrial, as well as aquatic ecosystems. In the case of the terrestrial ecosystems, the greatest possibilities of enhancing sequestration lie in increasing the absorption of carbon dioxide by plants in the photosynthesis process and mitigating the emission of $\mathrm{CO}_{2}$ from soil, by slowing down the oxidation of organic compounds in soils, e.g. by applying no tillage practice.

It is predicted that the increased $\mathrm{CO}_{2}$ content in ocean water will lead to its acidification and result in a decreased $\mathrm{CO}_{2}$ dissolution. Within the period from 1751 to 1994, the $\mathrm{pH}$ of ocean water dropped from 8.24 to 8.14 [13]. A decrease in the $\mathrm{pH}$ of ocean water negatively influences the ocean ecosystem, among others negative impact on coral reefs. Attempts are made to mitigate this phenomenon by enhancing the absorption of $\mathrm{CO}_{2}$ by algae in the photosynthesis process, carried out by fertilization of ocean waters with $\mathrm{Fe}$ ions. Intensification of algae growth enhances the absorption of $\mathrm{CO}_{2}$ by ocean waters and has a beneficial effect on fishing [14].

\section{Mitigation of climate changes by enhanced $\mathrm{CO}_{2}$ absorption in biomass}

Despite the negative changes connected with the accumulation of $\mathrm{CO}_{2}$ in the atmosphere, positive effects of increased $\mathrm{CO}_{2}$ concentration in the atmosphere, leading to increased biomass production, are observed as well. Many years of research conducted on various species of photosynthesizing organisms indicate that the increased $\mathrm{CO}_{2}$ concentration in the atmosphere intensifies the photosynthesis process $[15,16]$. A $10 \%$ 
increase of mean relative growth rate of seedlings of Betula pubescens in the 35-day greenhouse experiment, followed up by the increase of $\mathrm{CO}_{2}$ concentration in the atmospheric air from 350 to $560 \mu \mathrm{mol} \mathrm{mol}{ }^{-1}$, was observed by Mortensen [15]. Increased biomass production in the atmosphere containing $700 \mu \mathrm{mol} \mathrm{mol}^{-1}$ of $\mathrm{CO}_{2}$ was also observed in the case of grasses (Lolium perenne, Cynosurus cristatus, Holcus lanatus and Agrostis capillaris) in an 8-month experiment with the open-top chamber [15]. Moreover, the researchers stated that the particular grass species varied in their response to elevated $\mathrm{CO}_{2}$, not only in terms of biomass growth but also in species composition. Significant influence of elevated $\mathrm{CO}_{2}$ concentration was observed by Wang et al. [17] also in the case of rice. They stated that $\mathrm{CO}_{2}$ concertation in the range of 600-699 ppm enhanced the rice yield by $20 \%$ as compared to atmospheric conditions. According to Leakey [18] direct enhancement of photosynthesis by elevated $\mathrm{CO}_{2}$ concentration in the atmosphere is evident for the crops with $\mathrm{C}_{3}$ photosynthetic pathway. In the case of the crops with $\mathrm{C}_{4}$ pathway (mainly grasses and sedges), the direct stimulation of their growth by high $\mathrm{CO}_{2}$ concentration was not observed. However, such conditions positively influence the plant growth in the case of drought stress that was as a result of lower stomatal conductance and greater amount of intercellular $\mathrm{CO}_{2}$. Thus, $\mathrm{C}_{4}$ crops can only be benefited by elevated $\mathrm{CO}_{2}$ in the periods or the places with drought stress.

Intensification of biomass growth under the influence of increased $\mathrm{CO}_{2}$ concentration in the atmosphere can be considered as a factor contributing to the mitigation of climate changes. However, it should be remembered that not all plants react the same to an elevated concentration of $\mathrm{CO}_{2}$, and the growth of plants is dependent not only on the availability of $\mathrm{CO}_{2}$, but also a range of other factors, such as the content of $\mathrm{N}, \mathrm{P}, \mathrm{K}$ and other biogenic elements, as well as the access to water. If a single factor is at an inappropriate level, the increased $\mathrm{CO}_{2}$ concentration will not contribute to a raise in the biomass production.

On the other hand, at higher temperatures, dead organic matter will undergo faster mineralization in soil, which in turn will lead to an increased emission of $\mathrm{CO}_{2}$ from soils. Accelerated decomposition of organic compounds accumulated in soils, as a result of warming was observed by Cheng et al. [19]. They found that the microbial communities in warmed soils had higher relative abundance of key functional genes involved in the degradation of organic materials than those in the control soils. Thus, warming can enhance decomposition soil organic matter, which can significantly increase the $\mathrm{CO}_{2}$ flux to the atmosphere [20].

Increasing the retention of carbon in the biomass in soil will be possible through the intensification of the biomass production and slowing the rate of soil organic matter mineralization, for instance through the application of thick vegetation cover, mulching and no tillage practices.

Enhancement of carbon sequestration constitutes one of the main tasks of regenerative (and sustainable) agriculture, also known as agro ecological farming. The aim of regenerative farming systems is to increase the soil quality and biodiversity in farmland while ensuring the profitable production [21]. It encompasses a range of techniques, i.e. non-tillage, avoidance of leaving soil uncovered, integrating livestock and cropping operations on the land [22]. These actions aim at reconstructing and maintaining soil fertility as well as sequestering of carbon. One of the common practices is the application of catch crops, which enhance the $\mathrm{CO}_{2}$ absorption themselves and additionally constitute a layer covering soil [23]. The application of catch crops enables to increase the biomass production per unit of agricultural field. The biomass produced in such way may be left on 
the field as a green manure, which constitutes a source of nutrients and humus. Transformation of the organic compounds forming biomass into long-lasting humic compounds, characterized by high resistance to biodegradation, not only improves the physicochemical properties of soil, but also constitutes a method of carbon sequestration.

Moreover, the biomass of catch crops can be utilized for the production of biofuels, including the biogas produced in the methane fermentation process or syngas, bio-oil and biochar produced in the gasification and pyrolysis processes. These products constitute renewable sources of energy, which enable to reduce the consumption of fossil fuels [24]. This influences the mitigation of $\mathrm{CO}_{2}$ emission, because the carbon contained in the biomass used for biofuels production is captured from the atmosphere [25], and not extracted from deep geological strata. Therefore, it does not add new load of carbon to the global fluxes.

Residues from the biogas and syngas production, may also have a beneficial influence on the carbon cycle, if introduced to soil. They are a valuable fertilizer which improve the quality of soil and greatly contribute to permanent carbon sequestration in soil environment. The results of the studies carried out by Cayuela et al. [26] show the importance of this phenomenon. They analysed the fate of ten by-products from energy production from the biomass, such as digestate from anaerobic digestion of manure, first generation biofuel by-products (rapeseed meal, distilled dried grains), second-generation biofuel by-products (nonfermentables from hydrolysis of different lignocellulosic materials) and biochars. Each of the residues was added to a sandy soil in the same dose calculated on the basis of $\mathrm{N}$ rate $\left(150 \mathrm{~kg} \mathrm{~N} \mathrm{ha}^{-1}\right)$. The soils were incubated at $20^{\circ} \mathrm{C}$. The time-dependent loss of carbon in soil was measured for 60 days. The lowest losses of carbon, ranging between $0.5 \%$ and $5.8 \%$ of total added carbon were observed in the case of biochars, a $40 \%$ loss was noted for digestates, and for remaining residues, the losses ranged from 60 to $80 \%$. The loss of nitrogen from soils was also investigated. The nitrous oxide released from soil as a result of denitrification is an important greenhouse gas, with the GWP (Global Warming Potential) amounting to 265 for 100-year time horizon [2].

\section{Characterization of catch crops cultivation}

Catch cropping and intercropping is consider as an efficient strategy to deal with the climate changes [23]. Catch crops are the plants cultivated in pure or mixed sowing, in a period between two main crops [27]. Intercrops and catch crops mainly include the plants with a short vegetation period [28]. Many practical benefits for farmers, such as stable yields, limitation of weeds, pest and plant diseases, increase of protein content in cereals or decrease of nitrogen leaching can be achieved by catch crops and intercrops cultivation $[23,29]$. But the appropriate selection of crops species due to the climate and soil conditions is a basic element of an effective counteracting the climate changes and to obtain the benefits for agriculture.

Depending on the sowing time, three types of catch crops can be distinguished:

- Stubble crops - seeds are sown in summer, while the crops are harvested in autumn for green forage, mowed and filched or plowed without mowing. After mowing, plants may be also left for winter in the form of mulch. The plants which are most commonly cultivated as this type of crops include brassicas (white mustard, black mustard, rapeseed, oilseed radish, stubble turnip, Brassica oleracea var. medullosa), legumes (horse bean, yellow lupin, narrowleaf lupin, sugarsnap peas, field peas, spring vetch, 
serradella), and other species (blue tansy, sunflower, oat). While composing mixes, one should not include more than 2-4 plant species. At least one of these species should be adapted to the local habitat conditions and constitute 50-70\% of the sowing rate. The mixture should comprise the species with similar length of the vegetation period and application [28].

- Undersown crops - spring cereals sown in spring or, rarely, sown with winter cereals. They are used similarly to stubble crops in autumn (fodder, green forage biomass, mulch). The most common undersown crops include: small seeded Fabaceae (red clover, white clover, black medick, serradella), their mixtures with grasses, as well as grasses alone (Lolium westerwoldicum, orchard grass, perennial ryegrass, annual ryegrass, tall oat-grass).

- Winter catch crops - sown at the break of August and September and harvested in spring of the next year. The plants cultivated after their harvest are called secondary crops (e.g. potato, corn). Winter catch crops are categorized in accordance to their harvest period: early (winter agrimony, winter rapeseed), intermediate (winter rye, winter rye + hairy vetch, winter rye + hairy vetch + crimson clover), late (Lolium westerwoldicum, crimson clover, perennial ryegrass + winter vetch + crimson clover, annual ryegrass + winter vetch + crimson clover, perennial ryegrass + winter vetch, winter wheat + winter vetch) $[27,28]$.

The average yield of biomass (dry mass - d.m.) of the plants cultivated as catch crops in central Lubelskie Voivodeship, which is situated in temperate climate zone, with greater precipitation than evaporation, characterized by the average annual ambient temperature of ca $7.6{ }^{\circ} \mathrm{C}$, and mean precipitation of $540 \mathrm{~mm}$ [30] ranges from 2.64 to $4.26 \mathrm{Mg} \mathrm{d} . \mathrm{m} . / \mathrm{ha}$ (Table 3). White mustard presented the highest biomass yield per hectare. Carbon constitutes approximately $43 \%$ of the dry biomass in the above-ground parts of the plants presented in Table 3. This carbon can be contained for a longer time in a soil ecosystem, provided that biomass is used as green manure. The amount of carbon that remains in soil permanently and will not be released into the atmosphere in the form of $\mathrm{CO}_{2}$ depends mainly on the soil and climate conditions, such as porosity, humidity, temperature, etc.; these factors are also decisive in terms of what part of the root biomass remaining in soil will be transformed into humic compounds.

Mean yield of catch crops air dry mass [t/ha] obtained under the soil and climate conditions

Table 3 of central Lubelskie Voivodeship [31-33]

\begin{tabular}{|c|c|c|}
\hline Species & $\begin{array}{c}\text { Biomass } \\
{[\mathbf{M g} / \mathbf{h a}]}\end{array}$ & $\begin{array}{c}\text { Carbon included in the biomass } \\
{\left[\mathbf{M g} \mathbf{C O}_{2} / \mathbf{h a}\right]}\end{array}$ \\
\hline White mustard & 4.26 & 6.64 \\
\hline Spring rapeseed & 3.40 & 5.32 \\
\hline Blue tansy & 3.98 & 6.23 \\
\hline Red clover & 2.69 & 4.22 \\
\hline Serradella & 3.05 & 4.77 \\
\hline Spring vetch + field pea & 3.46 & 5.39 \\
\hline Narrow-leaf lupin + field pea & 2.64 & 4.11 \\
\hline Oats + spring vetch + pea & 3.22 & 5.02 \\
\hline Winter rye & 4.07 & 6.34 \\
\hline
\end{tabular}


Due to the beneficial effect on the environment, catch crops and intercrops can be treated as environmentally friendly agriculture [34]. In the last years, the interest in growing these crops has been on the constant increase among farmers.

\section{Assessment of catch crops role in terms of mitigation of carbon dioxide emissions in Poland}

Approximately 7.5 million hectares of cereals are cultivated in Poland [35]. This area is suitable for catch crops cultivation. Therefore, if catch crops were cultivated over the entire area, it would be possible to increase the annual absorption of $\mathrm{CO}_{2}$ from $30.8 \mathrm{Tg} \mathrm{CO} /$ year to $49.8 \mathrm{Tg} \mathrm{CO}_{2} / \mathrm{yr}$, achieving the biomass production ranging from $19.8 \mathrm{Tg}$ d.m./yr to $32.0 \mathrm{Tg}$ d.m./yr (assuming the biomass yield given in Table 3 ).

The biomass can be used as a substrate for green energy production. The studies on methane fermentation process indicated that the efficiency of methane generation ranged from 222 to $450 \mathrm{~m}^{3} / \mathrm{Mg}$ of volatile solids (VS), depending on the catch crop species $[36,37]$. Assuming the average total solid and VS contents equal to 25 and $90 \%$ respectively, the VS mass of the crops ranged from 17.8 to $28.8 \mathrm{Tg} / \mathrm{yr}$. This amount of the biomass would be sufficient to produce from $4.0 \cdot 10^{9}$ to $13.0 \cdot 10^{9} \mathrm{~m}^{3}$ of the methane per year. The methane yield of raw biomass is estimated at 50 to $101 \mathrm{~m}^{3} / \mathrm{Mg}$ and the methane yields per hectare at 685 to $1384 \mathrm{~m}^{3} / \mathrm{ha}$.

The produced biomass can also be utilized for other purposes, e.g. production of biochar and syngas in the pyrolysis or gasification processes. Assuming the average biomass conversion during slow pyrolysis to biochar, bio-oil, and syngas at 30, 40 and $30 \%$, respectively [38] the catch crops produced in Poland biomass could be converted to about 5.9-9.6 $\mathrm{Tg}$ of biochar, 7.9-12.8 $\mathrm{Tg}$ of bio-oil and 5.9-9.6 $\mathrm{Tg}$ of syngas. The syngas and bio-oil can be converted to energy and the biochar can be applied to soils, which enables long-term carbon sequestration, estimated even at 200 years [39], what would help to mitigate climate changes. These changes make a serious global problem, which can be alleviated only by developing multidimensional solutions [40, 41].

\section{Conclusions}

Cultivation of catch crops enables to increase the sequestration of $\mathrm{CO}_{2}$ in the agriculture sector. Assuming that all the surface area used for cereals cultivation in Poland, which equals 7.5 million hectares, will be allocated for catch cropping, from 4.11 to $6.64 \mathrm{Mg} \mathrm{CO}_{2} / \mathrm{yr}$ can be absorbed per one hectare of the cultivated crops, depending on the plant species. Simultaneously, catch crops cultivation allows producing from 4.46 to 7.20 Tg/yr of biomass, which may be used for green energy production, either by the generation of biogas in the anaerobic digestion process or syngas in thermochemical processes. Additionally, the residues obtained in these processes, such as digestate and biochar can be applied as valuable fertilizers or soil conditioners.

\section{Acknowledgements}

This article has been prepared as a part of the implementation of statutory tasks (No. FN-75/IŚ/2019 and No. FN-13/IŚ/2019) of the Faculty of Environmental Engineering of Lublin University of Technology. 


\section{References}

[1] IPCC. Forth Report Climate Change 2007: Impacts Adaptation and Vulnerability. Available from: https://www.ipcc.ch/report/ar4/wg2/.

[2] IPCC. Fifth Report, Climate Change 2013: The Physical Science Basis. Available from: https://www.ipcc.ch/report/ar5/wg1/.

[3] IPCC. Climate Change 2014, Impacts, Adaptation and Vulnerability. Available from: https://www.ipcc.ch/report/ar5/wg2/.

[4] Ryden L, Migula P, Andersson M. Environmental Science. Understanding, Protecting and Managing the Environment in the Baltic Sea Region. The Baltic University Programme. 2003: Uppsala University. Available from: https://www.researchgate.net/publication/314259676_Environmental_Science__Understanding_Protecting_and_Managing_the_Environment_in_the_Baltic_Sea_Region.

[5] Le Quéré C, Andrew RM, Friedlingstein P, Sitch S, Pongratz J, Manning AC, et al. Global Carbon Budget 2017. Earth Sust Sci Data. 2018;10:405-448. DOI: 10.5194/essd-10-405-2018.

[6] ESRL. Trends in Atmospheric Carbon Dioxide. Available from: https://www.esrl.noaa.gov/gmd/ccgg/trends/data.html.

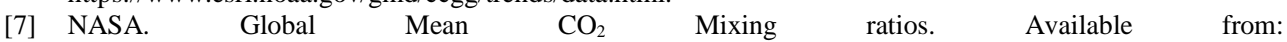
https://data.giss.nasa.gov/modelforce/ghgases/Fig1 A.ext.txt.

[8] IPCC Special Report: Global Warming of $1.5{ }^{\circ} \mathrm{C}$. Summary for Policymakers. Available from: https://www.ipcc.ch/sr15/chapter/summary-for-policy-makers/

[9] Olejnik TP, Sobiecka E. Problems Sust Development/Problemy Ekorozwoju. 2017;12(2):173-79. Available from: http://ekorozwoj.pol.lublin.pl/no24/t.pdf.

[10] Kruszczak E, Kierzkowska-Pawlak H. Ecol Chem Eng S. 2017;24(2):239-48. DOI: 10.1515/eces-2017-0016.

[11] Lal R. Science. 2004;304(5677):1623-7. DOI: 10.1126/science.1097396.

[12] Drastichová M. Problems Sust Development/Problemy Ekorozwoju. 2017;12(2):27-35. Available from: http://ekorozwoj.pol.lublin.pl/no24/e.pdf.

[13] Hall-Spencer JM, Rodolfo-Metalpa R, Martin S, Ransome E, Fine M, Turner SM, et al. Nature. 2008;454:96-99. DOI: 10.1038/nature07051.

[14] Trujillo AP, Thurman H. Essentials of Oceanography. $12^{\text {th }}$ edition. 2017. ISBN: 9780134073545.

[15] Mortensen LM. Environ Pollut. 1995;87(3):337-43. DOI: 10.1016/0269-7491(94)P4165-K.

[16] Jongen M, Jones B, Ann Bot-London. 1998;81(1):111-23. DOI: 10.1006/anbo.1998.0654.

[17] Wang H, Prentice IC, Keenan TF, Davis TW, Wright IJ, Cornwell WK, et al. Nat Plants. 2017;3:734-41. DOI: $10.1038 / \mathrm{s} 41477-017-0006-8$.

[18] Leakey ADB. Proc Biol Sci. 2009;276(1666):2333-43. DOI: 10.1098/rspb.2008.1517.

[19] Cheng L, Zhang N, Yuan M, Xiao J, Qin Y, Deng Y, et al. ISME J. 2017;11(8):1825-35. DOI: 10.1038/ismej.2017.48.

[20] Feng W, Liang J, Hale LE, Jung CG, Chen J, Zhou J, et al. Glob Chang Biol. 2017;23(11):4765-76. DOI: 10.1111/gcb.13755.

[21] Rodale R. Futurist. 1983;17(1):15-20. Available from: https://eric.ed.gov/?id=EJ275343.

[22] Motavalli P, Nelson K, Udawatta R. Jose S, Bardhan S. Int Soil Water Conservation Res. 2013;1(1):1-10. DOI: 10.1016/S2095-6339(15)30044-7.

[23] Venkateswarlu B, Shanker AK. Indian J Agronomy. 2009;54(2):226-30. Available from: https://www.researchgate.net/publication/200544373_Climate_change_and_agriculture_Adaptation_and_mit igation_stategies.

[24] Sobczyk W. Problems Sust Development/Problemy Ekorozwoju. 2014;9(1):119-26. Available from: http://ekorozwoj.pollub.pl/no17/p.pdf.

[25] Dołęgowska S. Problems Sust Development/Problemy Ekorozwoju. 2009:4(1):117-21. Available from: http://ekorozwoj.pol.lublin.pl/no7/k.pdf.

[26] Cayuela ML, Oenema O, Kuikman PJ, Bakker RR., van Groenigen JW. GCB Bioenergy. 2010;2:201-13. DOI: $10.1111 / \mathrm{j} .1757-1707.2010 .01055 . x$.

[27] Finch HJS, Samuel AM, Lane GPF. Lockhart \& Wiseman's Crop Husbandry Including Grassland. 9th ed. Cambrigde: Elsevier Ltd. 2014. ISBN: 9781782423713. DOI: 10.1016/C2013-0-23267-0.

[28] Hołubowicz-Kliza G. Uprawa poplonów. (Catch crops cultivation). Puławy: Wyd IUNG-PIB. Instrukcja upowszechnieniowa (Dissemination instruction). 166;2010. ISBN: 9788375620481.

[29] den Hollander NG, Bastiaans L, Kropff MJ. Eur J Agron. 2007;26(2):104-12. DOI: 10.1016/j.eja.2006.08.005. 
[30] Climate-data.org. Lublin climate. Available from: https://en.climate-data.org/europe/poland/lublinvoivodeship/lublin-622/.

[31] Kwiatkowski C, Harasim E. Acta Agroph. 2009;14(1):125-36. Available from: http://www.acta-agrophysica.org/Energy-effectiveness-of-spring-barley-production-in-crop-rotation-andmonoculture, $107324,0,2 . \mathrm{html}$.

[32] Kwiatkowski C, Juszczak J. Acta Agrob. 2011;64(2):69-76. DOI: 10.5586/aa.2011.019.

[33] Gawęda D, Acta Agrob. 2011;64(1):91-8. DOI: 10.5586/aa.2011.011

[34] Lithourgidis AS, Dordas CA, Damalas CA, Vlachostergios DN. Aust J Crop Sci. 5(4):396-410. Available from: https://www.researchgate.net/publication/224934832_Annual_intercrops_An_alternative_pathway_ for_sustainable_agriculture.

[35] GUS 2018. Land use and sown area in 2017. Warszawa: Central Statistical Office; 2018. Available from: https://stat.gov.pl/en/topics/agriculture-forestry/agriculture/land-use-and-sown-area-in-2017,7,13.html.

[36] Molinuevo-Salces B, Larsen SU, Ahring BK, Uellendahla H. Biomass Bioenerg. 2013;59:285-92. DOI: 10.1016/j.biombioe.2013.10.008.

[37] Peu P, Picard S, Girault R, Labreuche J, Béline F, Dabert P. Proc $13^{\text {th }}$ World Congress on Anaerobic Digestion Recovering (bio) Resources of the World. 25-28.06.2013. Available from: http://www.redbiogas.cl/wp-content/uploads/2013/07/IWA-11151.pdf.

[38] Irfan M, Lin Q, Yue Y, Ruan X, Chen Q, Zhao X, et al. BioRes. 2016;11(4):8929-40. DOI: 10.15376/biores.11.4.8929-8940.

[39] Matovic D. Energy. 2011;36:2011-6. DOI: 10.1016/j.energy.2010.09.031.

[40] Kroto HW, Zielińska M, Rajfur M, Wacławek M. Chem Didact Ecol Metrol. 2016;21(1-2):11-27. DOI: 10.1515/cdem-2016-0001.

[41] Johansson T, Pirouzfar P. Problemy Ekorozwoju - Problems Sust Development. 2019;14(2):33-44. Available from: http://ekorozwoj.pollub.pl/no28/e.pdf. 